\title{
Performance of Maritime Pine Spanish Mediterranean Provenances at Young Ages in a Transitional Region Between Atlantic and Mediterranean Climates in NW Spain
}

\author{
By R. DE LA MATA ${ }^{1),}$, and R. ZAS ${ }^{2)}$
}

(Received $23^{\text {th }}$ February 2009)

\begin{abstract}
Maritime pine (Pinus pinaster Ait.) occurs naturally in a wide variety of sites around SW Europe, from typical Mediterranean climates to areas in Northern Spain and France with a strong oceanic influence. Within its distribution range populations are strongly differentiated, showing local adaptations to environmental conditions that have been widely documented in different provenance trials both in the Atlantic region and in the Mediterranean area. In the present paper, we analyzed the performance of six Mediterranean provenances in three sites in the interior of Galicia (NW Spain), a transitional region between Atlantic and Mediterranean climates where few catalogued materials are available for reforestation. Seven year after planting, provenances coming from the mildest climates grew faster but showed inferior stem form. The provenance $x$ site interaction was weak, although some significant provenance rank changes were observed in the driest site. Among the tested provenances, Serranía de Cuenca showed good early growth in all sites and acceptable stem form, being thus a potential recommended material for using in the area. The Albarracín origin showed also good results, with excellent stem form and acceptable growth, especially in the driest site. A combined spatial analysis allowed us to compare the tested provenances with improved materials from Coastal Galicia (NW Spain) and Western Australia planted in adjacent progeny trials. Although the differences were small, the Atlantic material of both breeding programs performed slightly better than the Mediterranean provenances, and represents another alternative material for use in reforestation in this transitional climate region.
\end{abstract}

Key words: Pinus pinaster, provenance trial, spatial analysis, seed origin, genetic resources.

\section{Introduction}

Pinus pinaster Ait. occurs naturally in SW Europe and NW Africa. Inside of its distribution area (approximately 4 million hectares) it occurs in a wide variety of sites, where three main groups can be distinguished: an east group including western Africa, eastern Africa, northern Italy, Corsica and Sardinia, a second group formed by the populations from eastern, central and western of the Iberian Peninsula, including the Portugal populations,

1) Centro de Investigación Forestal de Lourizán. Apdo. 127, 36080 Pontevedra, Spain.

$\left.{ }^{2}\right)$ Misión Biológica de Galicia. CSIC. Apdo. 28, 36080. Pontevedra, Spain.

*) To whom correspondence should be addressed. Current address: Misión Biológica de Galicia. CSIC. Apdo. 28, 36080. Pontevedra, Spain. Phone: +34 986 854800. E-Mail: rmata. cifal@siam-cma.org. and a third group including the populations from northern Spain and France (BuCCI et al., 2007). Maritime pine has great economic importance all around its distribution area, and has been introduced out of its natural region for production purposes in countries such as New Zealand, Australia and South Africa.

$P$. pinaster is the most important forest productive species in Galicia (NW Spain), both in the coastal area with a typical Atlantic climate (annual precipitation = 1500-2500 $\mathrm{mm}$, annual temperature oscillation = $10-11^{\circ} \mathrm{C}$ ), and in the interior area with prolonged summer drought and wide thermal oscillation (annual precipitation $=600-1200 \mathrm{~mm}$, annual temperature oscillation $=13-14^{\circ} \mathrm{C}$ ) which constitutes a transition region to the more continental and Mediterranean typical climate of the central areas of the Iberian Peninsula. The climate in all the area is likely to become more similar to the one in central Spain in the near future. The predictions of local climate models in the area show an average annual temperature increase with more extremes of heat in the summer, fewer extremes of cold in the winter, and important changes in the distribution of rain over the course of the year (PÉREZ-MUÑUZURI et al., 2009).

According to the actual climatic differences between the coastal and the interior areas, two different provenance regions are recognized within Galicia, the northwest coastal (1a) and the northwest interior (1b) (ALÍA et al., 1996). The first one shows excellent growth traits and branch characteristics, and reasonable stem form, but in the inner region, the stands have clearly worse quality in relation to growth, stem form and branch habits (ALÍA et al., 1996). A breeding program was initiated in the coastal region in the 80's based on the high performance of the existing stands and nowadays there are three clonal seed orchards that supply genetically improved seeds for reforestation. However, the catalogued forest reproduction material approved for the inner region is limited to just three single selected stands, clearly insufficient to satisfy the plantation rate in this area. Most of the plantations are, thus, performed with seeds from other provenances of unknown behaviour in this region. Similarly, almost all the adult woodlands in the inner area of Galicia derived from plantations realized during the second half of the twentieth century with foreign seeds of unknown origin and dubious adaptation. Because of this poor performance, developing individual phenotypic selections within these stands is difficult, hampering the development of a breeding program for this region similar to the program in the coastal area. 
Multiple wide-range studies using different molecular markers revealed that maritime pine populations show a high geographic structuration of the intraspecific genetic variation (BuCCI et al., 2007; BuRBAN and PETIT, 2003; GonZÁLEZ-MARTínez et al., 2002). Populations are isolated, and frequently show strong adaptations to local environmental conditions, like specific substrates, rainfall regimes, elevation range, occurrence of fire, or frost frequency (FERNANDES and RigOLOT, 2007; GONZÁLEZMARTÍNEZ et al., 2004; TAPIAS et al., 2004). Water stress and cold hardiness are probably some of the main factors driving population divergence (CHAMBEL et al., 2007; GonzÁLEZ-MARTínez et al., 2002; GUYON and KREMER, 1982). Differentiation among provenances has also been widely documented for many quantitative traits in different provenance trials both in the Atlantic region (CORREIA et al., 2004; DANJON, 1994a; MOLINA, 1965) and in the Mediterranean area (AlíA et al., 1995; HARFOUCHE et al., 1995; MATZIRIS, 1982).

In one provenance trial established in the coastal area of Galicia under a typical Atlantic climate, the Atlantic provenances were superior in height growth and branch characteristics, the local provenance being the best one (MolinA, 1965). On the other hand, in a multi-location provenance trial established in five locations with different site indexes and climatic conditions in central Spain, the Atlantic provenances showed high growth only in the mildest sites, but showed bad adaptation when the drought period was long, while the Spanish medium mountain provenances developed well in all sites (ALÍA et al., 1995; AlÍA and Moro, 1996; AlíA et al., 2001).
Despite the data from these trials, we lack information about the performance of $P$. pinaster provenances in the transitional region objective of the present study. Thus, we analyzed the performance of six selected provenances of $P$. pinaster from the Mediterranean area of the Iberian Peninsula planted across three sites in the interior area of Galicia, three and seven years after planting to evaluate the feasibility to use this material in this region.

\section{Material and Methods}

\subsection{Genetic material and test sites}

Three provenance trials were planted in the inland area of Galicia (NW Spain) in March 2001 (Guntín and Laza) and June 2001 (Becerreá) (Table 1). The three sites were located within the Region of Identification and Utilization (RIU) of forest reproductive material number 2, which takes up most of the inland area of Galicia (GARCíA et al., 2001).

The climate in the inland region clearly differs from the coastal area, showing a notorious continental influence, with greater annual and daily temperature oscillation, and lower annual and, specially, summer precipitation. Becerreá is the coldest and highest among the three sites, winter snow being frequent. During the study period, minimum temperatures in this site dropped below zero around 50 days per year (Table 1), with snowfall episodes every year. Guntín and Laza show a marked Mediterranean influence, with lower annual and summer precipitation. The strongest sum-

Table 1. - Location and main climatic features of the Pinus pinaster provenance trials from planting to assessment date (2001-2007 period).

\begin{tabular}{|c|c|c|c|}
\hline & Becerreá & Guntín & Laza \\
\hline Longitude (W) & $7^{\circ} 10^{\prime} 32^{\prime \prime}$ & $7^{\circ} 40^{\prime} 42^{\prime \prime}$ & $7^{\circ} 29^{\prime} 32^{\prime \prime}$ \\
\hline Latitude $(\mathrm{N})$ & $42^{\circ} 50^{\prime} 16^{\prime \prime}$ & $42^{\circ} 54^{\prime} 02^{\prime \prime}$ & $42^{\circ} 02^{\prime} 24^{\prime \prime}$ \\
\hline Altitude (m) & 900 & 550 & 770 \\
\hline Aspect & $\mathrm{S}$ & W & NE \\
\hline Slope $(\%)$ & 30 & 3 & 18 \\
\hline \multicolumn{4}{|l|}{ Climate characteristics (period 2001-2007) } \\
\hline Annual precipitation (mm) & 1026 & 842 & 685 \\
\hline Summer precipitation $(\mathrm{mm})^{1}$ & 115 & 99 & 69 \\
\hline Range of summer precipitation (mm) & $65-177$ & $72-186$ & $19-105$ \\
\hline Gaussen Index ${ }^{2}$ & 8 & 34 & 70 \\
\hline Annual mean temperature $\left({ }^{\circ} \mathrm{C}\right)$ & 10.4 & 11.7 & 11.9 \\
\hline Annual temperature oscillation $\left({ }^{\circ} \mathrm{C}\right)^{3}$ & 13.1 & 13.3 & 13.7 \\
\hline Number of frost days $\left(\operatorname{Tmin}<0^{\circ} \mathrm{C}\right.$ ) per year & 58 & 38 & 29 \\
\hline Absolute minimum temperature $\left({ }^{\circ} \mathrm{C}\right)$ & -7.2 & -7.1 & -4.8 \\
\hline
\end{tabular}

${ }^{1}$ Rain fallen during the months of June, July and August.

${ }^{2}$ Gaussen $=\Sigma(2 \mathrm{~T}-\mathrm{P})$ for each month where $2 \mathrm{~T}>\mathrm{P}(\mathrm{P}:$ monthly precipitation $(\mathrm{mm}), \mathrm{T}$ : monthly mean temperature $\left({ }^{\circ} \mathrm{C}\right)$ ).

${ }^{3}$ Difference between the mean temperature of the warmest month and the mean temperature of the coldest month. 
mer drought occurs in Laza where a severe dry period occurred in the summer of 2005 (Table 1).

All the three trials follow a randomized complete block design with 10 replications and 5 tree-row-plots. Spacing was $3 \times 2 \mathrm{~m}$ in Guntín and Becerreá, and $2.5 \times 2 \mathrm{~m}$ in Laza, which is the typical spacing for $P$. pinaster plantations in this region.

Six Spanish provenances of the Mediterranean area, selected on the basis of the good characteristics for timber production of their natural stands and their performance in previous provenance trials (ALÍA et al., 2001; MoLINA, 1965) were tested in each site. The details of the climate characteristics of each provenance origin are shown in Table 2.

Each provenance trial was planted adjoin to a progeny trial with 111 first-generation half-sib families of the Coastal-Galician (CG) breeding program and 6 families of the breeding program developed in Western Australia (WA) upon crosses from plus trees selected within the Leiría provenance. These progeny trials follow a randomized complete block design with 25 replications of one tree-plots. Seedlings of these progeny trials were cultivated together with the provenances following the same nursery protocols. Both the provenance and the progeny trials were planted at the same time, with the same spacing and soil preparation, and were measured at the same dates. These progeny trials were extensively studied in a companion paper (DE LA MATA and ZAS, under revision).

Seedlings from both the provenance and the progeny trials were cultivated in relatively small containers (Superleach $125 \mathrm{~cm}^{3}$ ) over a long period (9 months for Guntín and Laza, and 12 months for Becerreá), which may have entailed root deformations and poor stability of the seedlings after planting, as has been observed previously in other maritime pine plantations in the area (ZAS et al., 2004).

\subsection{Assessments}

All the trees of each site were assessed for growth, stem form and branch characteristics three and seven years after planting, except those dead or badly suppressed. Ideally, to ensure a good correlation with performance at rotation age, assessment and selection within forest genetic trials should be delayed until at least half of the rotation age (FRANKLIN, 1979). Rotation age for Maritime pine in this region is around 30-35 years, but previous studies analyzing age-age correlations in this species revealed that selection can be reasonably effective when trees are about 8-12 years old (KREMER, 1992, DANJON, 1994b). For instance, in one of the longest provenance studies with $P$. pinaster, DANJON (1994a) found general stability of the provenance rankings between ages 10 and 36. Assessments at age 7 can be thus considered to reflect reasonably well provenance adaptation to local environmental conditions. Nevertheless, results presented here should be considered as preliminary results that should be confirmed with further assessments at older ages. Growth traits included total height $(\mathrm{H})$ measured with a pole in centimetres, and diameter at breast height (D) measured with a calliper in millimetres (only at age 7). Stem form and branch traits were assessed following GALERA et al. (1997). Stem form of each tree was evaluated by a straightness score (STR: 1 = straight to 6 = very crooked) and a stem leaning score (LEN: $1=$ vertical to $4=$ severe lean). The branching habit was assessed by the number of whorls (WH). A small forest road was constructed trough the Becerreá trial in 2005, affecting several trees of the trial. Only the three year-old assessment was thus available in this site.

\subsection{Correcting the spatial dependence}

Traits that showed non-random spatial structure were adjusted for spatial autocorrelation prior to the statistical analyses. Spatial adjustments were carried out using the Iterative Spatial Analysis (ISA) method (ZAS, 2006), which aims to correct the within block spatial heterogeneity not accounted for by the block design. The ISA method is based on prospecting the spatial structure of the dependent variable in each site by constructing the empirical semivariogram for the residuals adjusted for main effects with the SAS VARIOGRAM procedure (SAS-INSTITUTE, 1999), and fitting a theoretical semivariogram model with the SAS NLIN procedure (SAS-INSTITUTE, 1999). The spatial variation of the dependent variable is then modelled by the kriging method based on the theoretical model of the semivariogram and using the SAS KRIG2D procedure (SAS-INSTITUTE, 1999).

Table 2. - Main geographic and climatic features at the origin of the studied provenances.

\begin{tabular}{lcccccc}
\hline & Bajo Tiétar & $\begin{array}{c}\text { Sierra de } \\
\text { Gredos }\end{array}$ & $\begin{array}{c}\text { Montaña de } \\
\text { Soria-Burgos }\end{array}$ & $\begin{array}{c}\text { Serranía de } \\
\text { Cuenca }\end{array}$ & $\begin{array}{c}\text { Albarracín } \\
\text { Alcaraz }\end{array}$ & $\begin{array}{c}\text { Sierra Segura- } \\
\text { Alcaraz }\end{array}$ \\
\hline Longitude $(\mathrm{W})$ & $5^{\circ} 23^{\prime}-5^{\circ} 53^{\prime}$ & $4^{\circ} 17^{\prime}-5^{\circ} 10^{\prime}$ & $2^{\circ} 27^{\prime}-3^{\circ} 27^{\prime}$ & $0^{\circ} 53^{\prime}-2^{\circ} 25^{\prime}$ & $1^{\circ} 12^{\prime}-1^{\circ} 51^{\prime}$ & $1^{\circ} 57^{\prime}-3^{\circ} 00^{\prime}$ \\
Latitude $(\mathrm{N})$ & $39^{\circ} 50^{\prime}-40^{\circ} 05^{\prime}$, & $40^{\circ} 07^{\prime}-40^{\circ} 27^{\prime}$ & $41^{\circ} 43^{\prime}-41^{\circ} 56^{\prime}$ & $39^{\circ} 25^{\prime}-40^{\circ} 37^{\prime}$ & $40^{\circ} 03^{\prime}-40^{\circ} 25^{\prime} 3^{\circ} 46^{\prime}-38^{\circ} 46^{\prime}$ \\
Altitude $(\mathrm{m})$ & 400 & $600-1400$ & $800-1200$ & $800-1200$ & $1000-1400$ & $800-1400$ \\
Annual precipitation $(\mathrm{mm})$ & 1060 & 1398 & 686 & 684 & 878 & 787 \\
Summer precipitation $(\mathrm{mm})$ & 70 & 83 & 105 & 101 & 155 & 65 \\
Annual mean temperature $\left({ }^{\circ} \mathrm{C}\right)$ & 14.4 & 13.4 & 11.3 & 12.3 & 9.6 & 13.7 \\
Mean of min temperatures $\left({ }^{\circ} \mathrm{C}\right)^{1}$ & 1.5 & -0.2 & -2.5 & -1.1 & -4 & 2.4 \\
Thermal oscillation $\left({ }^{\circ} \mathrm{C}\right)^{2}$ & 13.2 & 11.6 & 11.2 & 13.1 & 12.1 & 11.7 \\
\hline
\end{tabular}

${ }^{1}$ Mean of daily minimum of the month of lowest average $\left({ }^{\circ} \mathrm{C}\right)$.

2 Thermal oscillation $\left({ }^{\circ} \mathrm{C}\right)$ : Annual mean of the diary oscillation. 
Then, the original variable is adjusted for its spatial autocorrelation, subtracting the kriging estimate in each position. The new corrected variable is then reanalyzed and new estimates of the main effects are obtained, and used to generate new residuals. The process was repeated iteratively, until convergence of the main effect estimates (usually 5 steps are enough). A detailed description of the method can be consulted in ZAS (2006).

In each site, the spatial adjustments were carried out simultaneously for the provenance trial and the neighbouring progeny trial, assuming both the provenances and the families as a single main factor to obtain the residuals that were spatially modelled.

\subsection{Statistical analyses}

All analyses were based on plot means data. A joint analysis of the three sites together was carried out for each trait using the following mixed model:

$$
Y_{i j k}=\mu+S_{i}+P_{j}+B C_{k}\left(S_{i}\right)+S x P_{i j}+\varepsilon_{i j k}
$$

where $Y_{i j k}$ is the value of the plot $i j k, \mu$ is the overall mean, $S_{i}$ is the fixed effect of site $i, P_{j}$ is the fixed effect of the provenance $j, B C_{k}\left(S_{i}\right)$ is the random effect of the block $k$ within site $i, S x P_{i j}$ is the fixed interaction between the site $i$ and the provenance $j$, and $\varepsilon_{i j k}$ is the random error term. Provenance was considered a fixed factor because inference was limited to the six provenances tested. To analyse these mixed models the SAS MIXED procedure was used. Pairwise statistical comparisons of provenance means was conducted using the DIFF option of the LSMEANS statement of the MIXED procedure, which performs t-tests for the statistical significance of the difference between the least square means of all possible provenance means (SAS-INSTITUTE, 1999).

The performance of the tested provenances was also compared with the material tested in the adjacent progeny trials. Despite that the provenance and the progeny trials were two independent neighbouring trials, comparisons between them were reliable because the common spatial adjustments accounted for the eventual local microenvironmental differences between both trials. Within each site, we compared the performance of the best of the six provenances, the best of the six WA families, and the mean performance of the best 18 out of the 111 CG families included within each progeny trial (i.e., applying a 1:6 selection intensity within each group). We tested for statistical differences between the different genetic groups by constructing the confidence intervals at $95 \%$ for the mean of each group. Non overlapping confidence intervals were interpreted as significance differences.

\section{Results}

Residuals after subtracting family effects revealed pronounced non-random spatial structures for the growth traits and the number of whorls in the three test sites. Stem form traits revealed random spatial structures with the exception of the Becerreá trial where STR and LEN revealed slight spatial autocorrelation. The spatial structure for most of the traits was well represented by a spherical theoretical semivariogram $\left(\mathrm{r}^{2}>0.85, \mathrm{p}<0.001\right)$. Patch sizes ranged between 34 and $112 \mathrm{~m}$. The percentage of total residual variation explained by the spatial pattern varied from $10.6 \%$ for $\mathrm{WH}$ in Becerreá at age 3 to $73.2 \%$ for $\mathrm{H}$ in Laza at age 7. Height at age 7 was the trait that showed the largest intensities of spatial dependence.

The block structure of the experimental design absorbed part of the within site environmental variation, as revealed by significant among-block variances in all sites in the unadjusted analyses. However, the block variance was clearly lower than the percentage of variation explained by the spatial pattern, indicating that the block designs were not enough for absorbing all the spatial variation (data not shown). After the spatial adjustments the block variance became zero, and the residual variation decreased significantly in all cases. Additional$\mathrm{ly}$, the $\mathrm{F}$ ratio for testing the provenance effects substantially increased after the spatial adjustments. For some traits, such $\mathrm{H}$ and NW at age 7, significant differences between provenances were only detected after the spatial corrections.

Table 3. - Results of the mixed model for the analysis of different traits in three $P$. pinaster provenance trials in inner Galicia (NW Spain). F-ratios and significance levels ${ }^{1}$ are presented.

\begin{tabular}{clrlrlll}
\hline AGE & TRAITS & \multicolumn{2}{c}{ SITE (S) } & PROVENANCE (P) & \multicolumn{2}{c}{ S x P } \\
\hline 3 years & Height & 261.41 & $* * *$ & 8.75 & $* * *$ & 1.87 & $*$ \\
& N Whorls & 55.40 & $* * *$ & 9.71 & $* * *$ & 1.50 & \\
& Leaning & 95.63 & $* * *$ & 2.80 & $*$ & 2.59 & $* *$ \\
& Straightness & 11.20 & $* * *$ & 3.80 & $* *$ & 1.29 \\
\hline 7 years & Height & 61.07 & $* * *$ & 2.55 & $*$ & 1.68 \\
& Diameter & 36.87 & $* * *$ & 1.29 & & 0.77 & 0.78 \\
& N Whorls & 0.00 & & 2.61 & $*$ & 1.78 \\
& Leaning & 5.36 & $*$ & 12.86 & $* * *$ & 1.05 \\
\hline
\end{tabular}

${ }^{1}$ Significance levels: $* * *=\mathrm{P}<0.001, * *=\mathrm{P}<0.01, *=\mathrm{P}<0.05$. 
a)

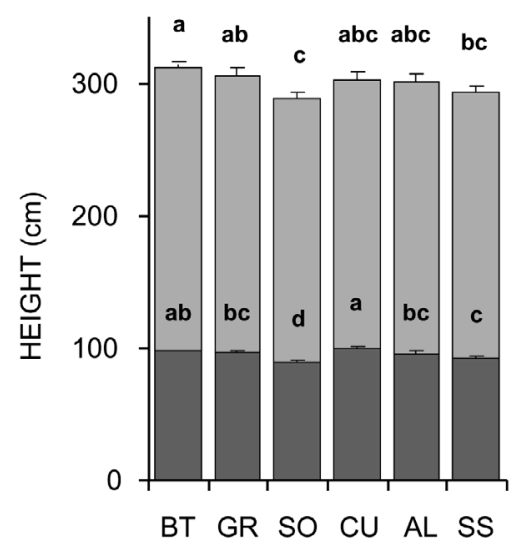

c)

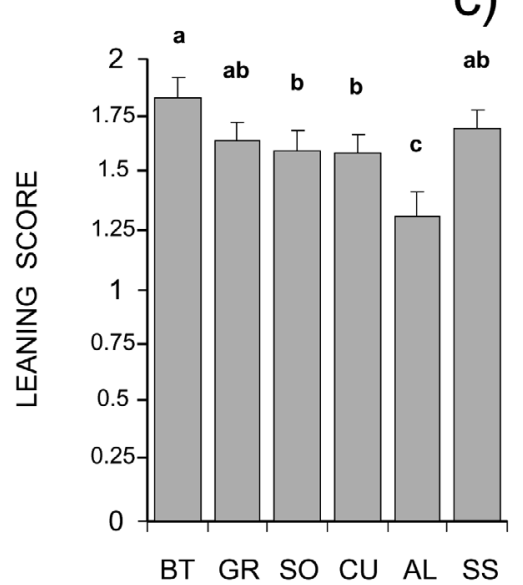

b)

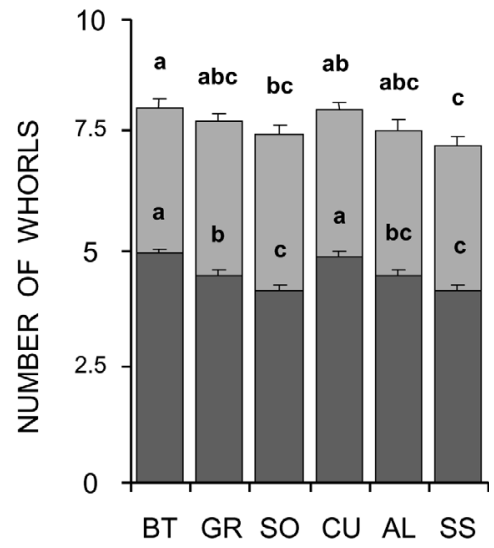

d)

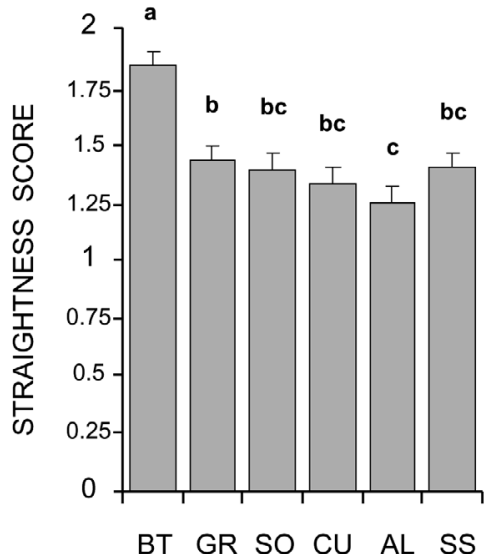

Figure 1. - Performance of 6 P. pinaster provenances for different traits across 3 provenance trials in inner Galicia (NW Spain). Provenances with the same letter are not significantly $(\mathrm{p}<0.05)$ different $(\mathrm{t}$-test for differences between least square means). Dark gray bars denote traits assessed at age 3 and light grey bars denote traits assessed at age 7. Provenance codes: BT = Bajo Tietar, GR = Sierra de Gredos, SO = Montaña de Soria-Burgos, CU = Serranía de Cuenca, AL = Albarracín, SS = Sierra de Segura-Alcaraz. Straightness score varied from 1 (straight) to 6 (crooked), and leaning score varied from 1 (vertical) to 4 (leaned).

Differences among sites were significant $(p<0.05)$ for all traits at age 3 , and for H, D, LEN and STR at age 7 (Table 3). After spatial adjustments, the provenance effect was significant $(\mathrm{p}<0.05)$ for height growth and for all the stem form traits at both ages (Table 3). Regarding height growth at age 3, Bajo Tiétar (BT) and Serranía de Cuenca (CU) showed the best performance, whereas Sierra de Segura-Alcaraz (SS) and Montaña de Soria-Burgos (SO) were the worst (Figure 1a). For height growth at age 7, Bajo Tiétar maintained the largest growth, Sierra de Gredos (GR) being the second one. Serranía de Cuenca lost some positions at age 7 with respect to age 3 . Sierra de Segura-Alcaraz and Montaña de Soria-Burgos continued showing the worst growth.

Bajo Tietar and Serranía de Cuenca, the two provenances that grew faster, had the highest values for the number of whorls, indicating strong polycyclism. On the other hand, Sierra de Segura-Alcaraz and Montaña de Soria-Burgos showed the lower number of whorls, weak polycyclism, and poor growth (Figure $1 b$ ).

The best provenance for stem form traits was Albarracín (AL), and the worst ones Bajo Tietar and Sierra de Gredos, which however were among the provenances with best growth (Figure 1).

The provenance $x$ site interaction was significant only for height growth and stem leaning at age 3 (Table 3 ). The reaction norms for these two traits across the three sites are shown in Figure 2. The ranking of the six provenances regarding height growth was very similar in Becerreá and Guntín, but showed large changes in Laza. Sierra de Gredos grew well in this site but not as well in Guntín and Becerreá, whereas Sierra de SeguraAlcaraz and Bajo Tietar were the worst provenances in Laza but they performed relatively well in Guntín and Becerreá. In the case of stem leaning, the interaction is 

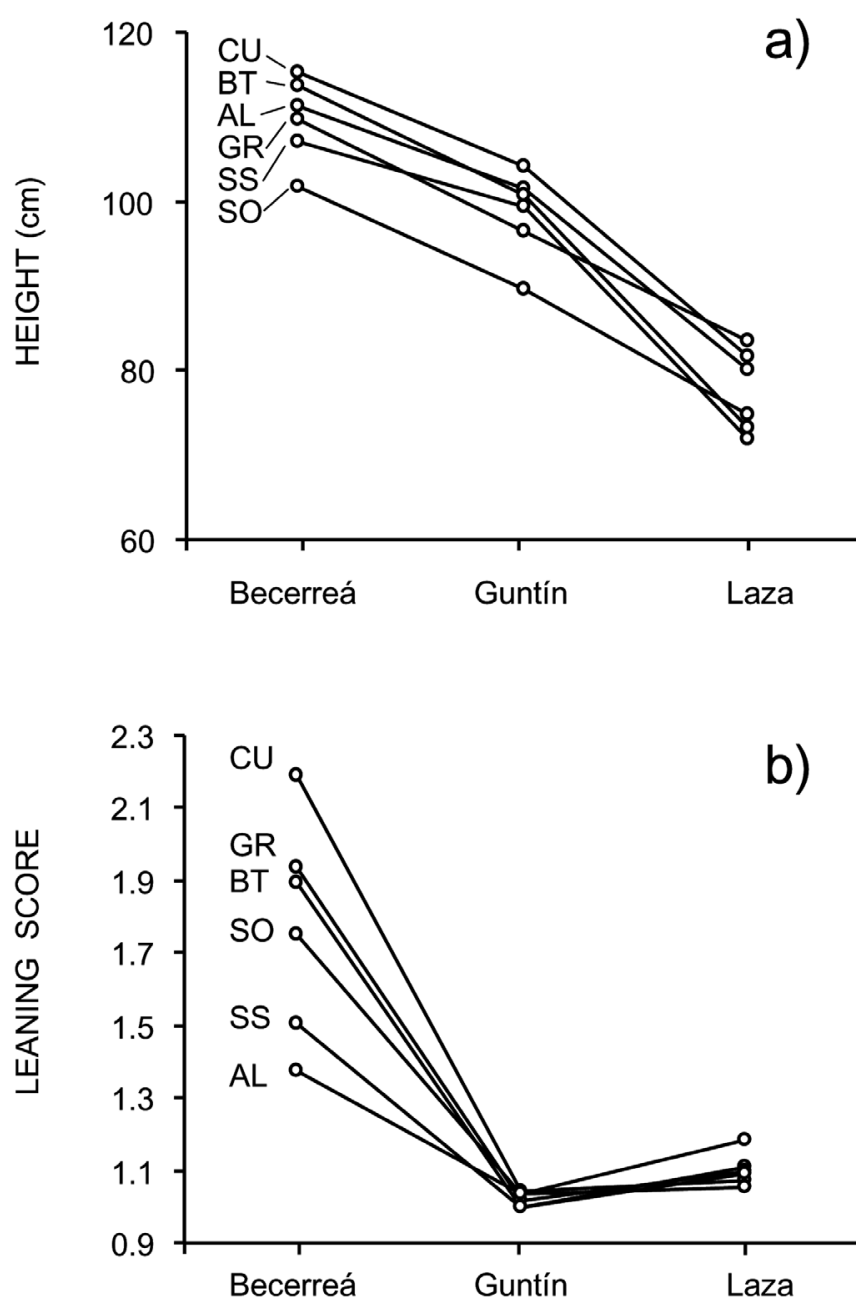

Figure 2. - Reaction norms of 6 P. pinaster provenances across three test sites in inner Galicia (NW Spain) for height growth (a) and stem leaning (b) at age 3. Provenance codes: BT = Bajo Tietar, GR = Sierra de Gredos, SO = Montaña de Soria-Burgos, $\mathrm{CU}=$ Serranía de Cuenca, $\mathrm{AL}=$ Albarracín, $\mathrm{SS}=$ Sierra de Segura-Alcaraz. Leaning score varied from 1 (vertical) to 4 (leaned).

likely to be due to a scale effect derived from the large phenotypic variation observed in the Becerreá trial for this trait (Fig. 2b). The interaction was not significant at age 7 for any trait.

Differences among provenances and the CG and WA families of the neighbouring progeny trials were small for all traits and sites, but the WA material and the halfsib CG families tend to have, in average, always higher growth, better stem form, and lower number of whorls than the mean performance of the six provenances in the three sites (data not shown). In addition, the material of WA performs slightly better than the half-sib CG families (see DE LA MATA and ZAS, under revision, for details). These results are maintained when comparisons are restricted to the best provenance, the best WA family and the 18 best CG families, i.e., applying a single trait selection of 1:6 intensity (Figure 3). The best families from either WA or CG grew significantly better in Laza and Guntin, whereas no significant differences were detected in Becerreá. Although the best WA and
CG families tend to have fewer whorls and better stem form than the best provenance in the three sites, differences among them were not significant, except for LEN in Laza.

\section{Discussion}

\subsection{Spatial autocorrelation}

The results indicated a strong spatial autocorrelation for all the growth variables with patchy structures and relatively large patch sizes. The block structure of the experimental designs was not enough to account for this spatial heterogeneity, and blocks were internally heterogeneous, violating the main assumption of the block designs. Conventionally analysis of this spatially autocorrelated data may give erroneous results, and adjustments for microenvironmental variation become essential (DuTKOWsKi et al., 2006; ZAs, 2006). As observed in other studies, the spatial adjustment removed block effects and strongly reduced residual variation, favouring the detection of significance differences among provenances. Indeed, for some traits, significant differences among provenances were only detected after the spatial analysis.

Another important feature of the spatial analysis we used is that it allowed us to compare the genetic material included in the two adjoin but independent trials within each site. Using conventional approaches, comparisons between these trials may be confounded with microsite environmental effects, which can not be absorbed by the two independent experimental designs. However, using the iterative spatial analysis (ISA) method (ZAS, 2006) we were able to account simultaneously for the spatial heterogeneity of both trials, allowing us the comparison among the genetic materials of both trials (see later).

\subsection{Provenance performance}

Superiority of local provenance in height growth and survival at age 18 found by MoLINA (1965) in a provenance trial established in the coastal area of Galicia was found by other authors too (CORREIA et al., 2004; DANJON, 1994a), suggesting that a great part of genotypic variability in $P$. pinaster is a result of local adaptations to environmental conditions through natural selection. Accordingly, in the provenance trial installed in central Spain (AlÍA et al., 1995; AlÍA et al., 2001) assessed at age 19 and 32, the Atlantic provenances showed bad adaptation when the drought period was long, and were clearly surpassed by other Mediterranean provenances. The Spanish medium mountain provenances (Sierra de Gredos, Montaña de Soria-Burgos and Serranía de Cuenca) developed well in all sites of this trial, showing the feasibility of their use in the interior areas of Spain (ALÍA and MoRO, 1996). The results presented here indicate that, in this transitional region between Atlantic and Mediterranean climates, the provenances from origins with a high Atlantic influence (Sierra de Gredos and Bajo Tietar) were the ones that grew faster, and thus were apparently the best adapted to the local environmental conditions of this region. Specifically, the good performance in height 
growth of Sierra de Gredos, an origin with a strong Atlantic influence and high precipitations (Table 2), coincides with MolinA (1965) and with the good height and diameter growth in the Mediterranean region of Spain (AlíA et al., 1995; AlíA and MoRo, 1996; AlíA et al., 2001), suggesting a high phenotypic plasticity and versatility for using this provenance across a wide range of climatic variation. Bajo Tietar provenance was the best in height growth, but the worst regarding stem form. This agrees with the typical characteristics of the stands in this origin (AlíA et al., 1996) showing, as in the case of Sierra de Gredos, an intermediate behaviour between Atlantic and Mediterranean provenances, but with poor stem form and spiraled stems. Serranía de Cuenca also performed well in height growth, and showed acceptable stem form, as the natural stands in the origins do (AlíA et al., 1996). It is important to remark here that this is one of the most variable seed sources, perhaps because of its large size and heterogeneous environments, and because this area was one of the most important glacial refuges in southern Europe, from where the species spread (CARRIÓN et al., 2003; SALVADOR et al., 2000). Within this large provenance region, the Boniches source was among the best in height growth in the Spanish provenance trials (AlíA et al., 1995; AlÍA et al., 2001). The remainder tested provenances, Montaña Soria-Burgos, Sierra de Segura Alcaraz, and Albarracín, showed poor growth but were among the best regarding stem form traits. In other provenances trials these origins showed intermediate performance both in growth and in stem form quality.

In the provenance trial established in central Spain, the best form was presented by mountain's provenances such as Moroccan, Corsican, Sierra de Gredos and some origins of Serranía de Cuenca, which agrees with the results from other provenance trials in Portugal assessed at age 8 (CoRREIA et al., 2004), France at age 36 (DANJON, 1994a), Greece at age 9 (MATZIRIS, 1982) and coastal Galicia at age 18 (MoLINA, 1965), suggesting that this kind of traits are less affected by environmental conditions. In agreement with these results, Sierra de Cuenca showed acceptable stem form in our trial series, as Montaña de Soria-Burgos did, which also showed excellent stem form in the coast of Galicia (Molina, 1965). However, contrary to previous results (AlÍA et al., 1995; AlÍA and Moro, 1996; AlÍA et al., 2001), Sierra de Gredos did not show good stem form in our trials, whereas Albarracín showed clearly the best stem characteristics although in other provenance trials this origin showed intermediate stem form qualities. These contradictory results may arise because seedlings in our trial series were cultivated in nursery in relatively small containers over a long period, favouring root deformations and poor anchorage after planting. Stability problems of containerized seedlings, resulting in stem leaning and strong stem curvatures have been reported before (LARIO and OCAÑA, 2004), and may alter comparisons among different genetic entries (CLIMENT et al., 2008). It should be noted that those provenances with better height growth are those with the worst stem form. This negative correlation between growth and stem form has been commonly observed in other prove- nance and progeny trials (AGUIAR et al., 2003; CORREIA et al., 2004; DANJON, 1994a; MATZIRIS, 1982; MolinA, 1965), and it could be amplified in our provenance trial because those provenances that grow faster are likely to have larger root systems within the small containers and thus more rooting problems and worse stem form in the field.

\subsection{Provenance $x$ Site interaction}

In disagreement with the results obtained in central Spain (AlíA et al., 1997; CHAMBEL, 2006) the provenance $x$ site interaction was weak, probably because the number of provenances tested and the number of test sites was much lower. With respect to height growth, Guntín and Becerreá sites behave in a similar way, whereas provenances in Laza performed relatively differently, showing the larger ranking changes (Fig. 2). From a climatic point of view, the most important difference among the test sites that could explain this pattern is the summer drought, reduced in Becerreá and Guntín, and pronounced in Laza (Table 2). This result is suggesting that summer drought is one of the most important factors driving maritime pine differentiation (DANJON, 1994a), and differences in local adaptations to this limiting factor among populations are expressed differentially in each test site, depending on the drought intensity.

In the case of stem leaning, the provenance $x$ site interaction probably arises from a scale effect due to very large variation in Becerreá in relation to the other two sites (Fig. 2), probably as the result of the strong slope of this test site, the high frequency of snow storms, and the root problems mentioned earlier, which are supposed to be stronger in this site because it was planted three months after the others. The interaction was not significant at age 7 , probably because only two sites were analyzed at this age, and because of a reduction of interaction with time, as observed by other authors (AlÍA et al., 1997).

\subsection{Comparison with the improved coastal material}

When we compare the tested provenances with the CG and WA improved material tested in the adjacent progeny trials, we can see that both improved materials had slightly better performances than the Mediterranean provenances, although the differences were minimal (Fig. 3). Nevertheless, the improved materials showed reasonably good adaptation to the interior of Galicia, reflecting the genetic gain due to selection in the respective breeding programs. These results suggest the versatility of the materials from these breeding programs to be used in different climatic regions, taking advantage of the added genetic gain obtained in the advance of the selection processes (DE LA MATA and ZAS, under revision). Considering these results, extending the deployment zone of the coastal maritime pine to inner areas where summer drought and/or winter cold is harder seems to be possible.

\subsection{Practical implications}

Two weak spots are behind the results of the present paper. First, although age 7 is a reasonable age for selection purposes in this fast growing pine species (see 

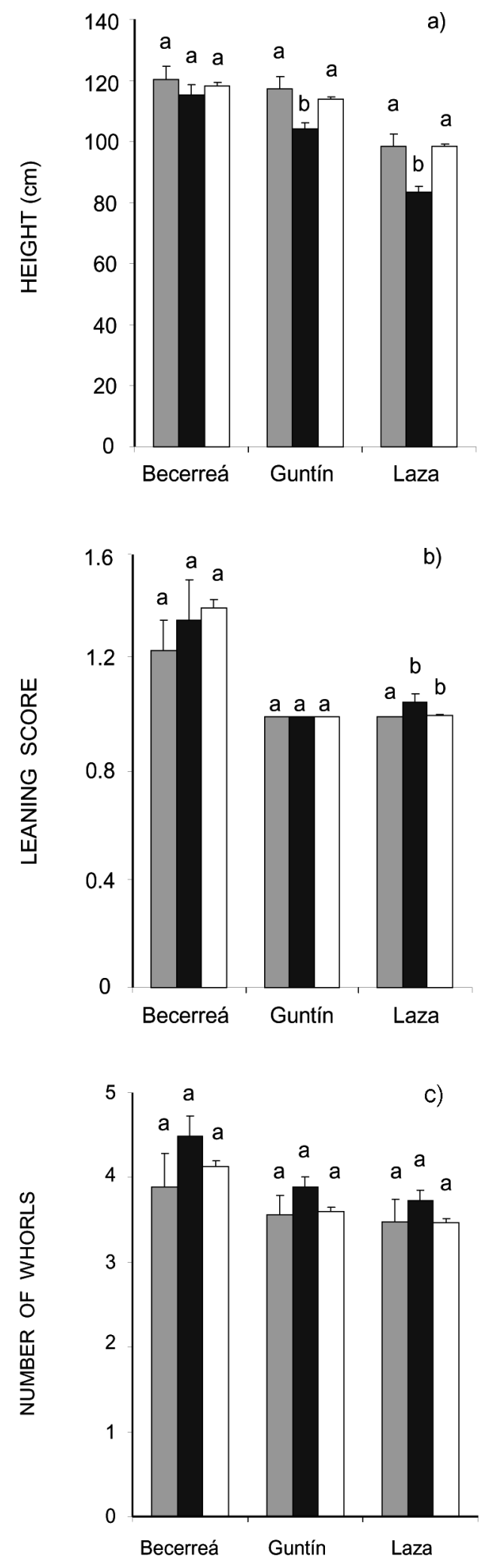

$\square$ WA family $\square$ Provenance $\square 18$ CG families

Figure 3. - Performance of the best $P$. pinaster provenance (Black bars), the best Western Australia (WA, gray bars) family and the mean performance of the best 18 Coastal-Galicia families (CG, white bars) in three test sites in inner Galicia (NW Spain), for three representative traits at age 3. Leaning score varied from 1 (vertical) to 4 (leaned). Within each site, different letters denote non overlapping confidence intervals $(\mathrm{a}=0.05)$ for the means.
Material and Methods), 7 years in the field is probably a too short period to reflect provenance adaptation to local climate conditions. Future extreme climate episodes such as severe droughts or extreme low temperatures in winter or spring may alter the observed provenance ranking. Thus, the results and practical recommendations offered here should be managed with care and should be confirmed with further assessments at older ages. Second, the expected climate change in the area may also alter the relative performance of the studied provenances. Local climate models predict an increase in temperatures, especially in summer, and important changes in the distribution of precipitation over the year, with a progressive evolution towards more Mediterranean conditions (PÉREZ-MUÑUZURI et al., 2009). Depending on how these predictions are fulfilled, the results and recommendations presented here would be more or less valid. Nevertheless, in the worse scenario, the Atlantic climate in the Coastal area would become more similar to the actual climate in interior Galicia, so the results presented here would be especially relevant to understand how the studied materials would respond to climate change in coastal areas.

Despite the limitations commented above, the results presented here offer valuable information to identify suitable reproductive forest material to be used in the interior of Galicia. As a final practical recommendation, Sierra de Cuenca is the provenance with better performance in all sites, with high height growth and relatively good stem form, being thus, a recommended material for using in the interior area of Galicia. However, this provenance is very variable (AlíA et al., 1996), and different stands within the region could give very different results (F.J. Lario, personal communication). Albarracín showed also good results, being the best in stem form and showing acceptable growth in the three sites. Being a provenance well adapted to summer drought (ALÍA et $a l ., 1996)$, it can be recommended for using in the driest areas of interior Galicia.

Importing seeds from the recommended provenance regions according to the results obtained in the present work represents a clear alternative to supply forest reproductive material for use in afforestation in the interior of Galicia. However, the use of improved material from the CG and WA breeding programs should probably be preferred. To exploit the genetic gains of these programs in the inner area of Galicia, different selection strategies can be considered, among which we stick out the conversion of the progeny trials in breeding seedling orchards, or the selection within the family trials of a new breeding population from which new clonal seed orchards can be established.

\section{Acknowledgements}

This study was supported, during the last years, by the INIA projects RTA05-173 and RTA07-100. The series of trials was established under the supervision of Guillermo Vega and Josefa Fernández-López. We thank ANA HERNÁNDEZ for her helpful participation in data processing and field assessments, Dr. EsTHER MERLO for stimulating discussion on the results, PABLO 
XESTEIRA for helping in trial maintenance, and RICARDO Ferradás, Raquel Jares, Manuel Cerviño, Emilio PÉrez, Xoaquín Moreira and Patricia Martíns for field assessments. We greatly acknowledge comments by Dr. LUIS SAMPEDRO and two anonymous referees that clearly helped to improve the quality of the paper. We also thank BENITO SANTOS for reviewing the language.

\section{References}

Aguiar, A., M. H. Almeida and N. Borralho (2003): Genetic control of growth, wood density and stem characteristics of Pinus pinaster in Portugal. Silva Lusitana 11: 131-139.

Alía, R., L. Gil and J. A. Pardos (1995): Performance of 43 Pinus pinaster Ait. provenances on 5 locations in central Spain. Silvae Genet 44: 75-81.

Alía, R., S. Martin, J. De Miguel, R. Galera, D. Agúndez, J. Gordo, G. Catalán and L. Gil (1996): Las regiones de procedencia de Pinus pinaster Ait. OA de Parques Nacionales. DGCONA, Madrid, 75 p.

AlíA, R. and J. Moro (1996): Comportamiento de procedencias de Pinus pinaster Ait. en el centro de España. Invest Agr. Sist Rec For 5: 57-75.

AlíA, R., J. Moro and J.-B. Denis (2001): Ensayos de procedencias de Pinus pinaster en el centro de España: resultados a la edad de 32 años. Invest Agr. Sist Rec For 10: $333-354$.

AlíA, R., J. Moro and J. B. Denis (1997): Performance of Pinus pinaster provenances in Spain: interpretation of the genotype by environment interaction. Can J For Res 27: 1548-1559.

Bucci, G., S. C. Gonzalez Martinez, G. Le Provost, C. Plomion, M. M. Ribeiro, F. Sebastiani, R. Alia and G. G. Vendramin (2007): Range-wide phylogeography and gene zones in Pinus pinaster Ait. revealed by chloroplast microsatellite markers. Mol Ecol 16: 2137-2153.

Burban, C. and R. J. Petit (2003): Phylogeography of maritime pine inferred with organelle markers having contrasted inheritance. Mol Ecol 12: 1487-1495.

Carrión, J. S., E. I. Yll, M. J. Walker, A. J. Legaz, C. CHAIN and A. LOPEZ (2003): Glacial refugia of temperate, Mediterranean and Ibero-North African flora in south-eastern Spain: new evidence from cave pollen at two Neanderthal man sites. Glob Ecol Biogeogr 12: 119-129.

Climent, J., J. Alonso and L. GiL (2008): Root restriction hindered early allometric differentiation between seedlings of two provenances of Canary Island Pine. Silvae Genet 57: 187-193.

Correia, I., H. Almeida and A. Aguiar (2004): Variabilidade do crescimento e da forma de proveniencias de Pinus pinaster Aiton aos 8 anos, na Mata nacional do Escaroupim. Silva Lusitana 12: 151-182.

Chambel, M. R. (2006): Variabilidad adaptativa y plasticidad fenotípica en procedencias de pinos ibéricos. Thesis. Dpto. de Silvopascicultura. Universidad Politécnica de Madrid, $118 \mathrm{p}$.

Chambel, M. R., J. Climent and R. Alía (2007): Divergence among species and populations of Mediterranean pines in biomass allocation of seedlings grown under two watering regimes. Ann For Sci 64: 87-97.

DANJON, F. (1994a): Stand features and height growth in a 36-year-old maritime pine (Pinus pinaster Ait.) provenance test. Silvae Genet 43: 52-62.
DANJON, F. (1994b): Heritabilities and genetic correlations for estimated growth curve parameters in Maritime pine. Theor Appl Genet 89: 911-921.

DE LA MATA, R. and R. ZAS (under revision): Transferring Atlantic maritime pine improved material to regions with marked Mediterranean influence in inland NW Spain. A likelihood-based approach on spatially adjusted field data. Submitted.

Dutkowski, G. W., J. Costa-Silva, A. R. Gilmour and G. A. Lopez (2002): Spatial analysis methods for forest genetic trials. Can. J. For. Res. 32: 2201-2214.

Fernandes, P. M. and E. Rigolot (2007): The fire ecology and management of maritime pine (Pinus pinaster Ait.). For Ecol Manage 241: 1-13.

FrankLIN, E. C. (1979): Model rating levels of genetic variance to stand development of four North American conifers. Silvae Genet 25: 207-212.

Galera, R., S. Martin, R. Alía, J. Gordo, A. M. Aguado and E. Notivol (1997): Manual de selección de masas productoras de semillas. Evaluación de caracteres. Ministerio de Agricultura, Pesca y Alimentación. INIA, Madrid, $92 \mathrm{p}$.

García, J. M., J. De-Miguel, R. Alía and S. Iglesias (2001): Regiones de Identificación y Utilización de material forestal de reproducción. Ministerio de Medio Ambiente. Serie Cartográfica, Madrid, 293 p.

González-Martínez, S. C., R. AlíA and L. Gil (2002): Population genetic structure in a Mediterranean pine (Pinus pinaster Ait.): a comparison of allozyme markers and quantitative traits. Heredity 89: 199-206.

González-Martínez, S. C., S. Mariette, M. M. Ribeiro, C. Burban, A. Raffin, M. R. Chambel, C. A. M. Ribeiro, A. Aguiar, C. Plomion, R. Alia, L. Gil, G. G. VenDramin, A. Kremer and M. P. Reviron (2004): Genetic resources in maritime pine (Pinus pinaster Aiton): molecular and quantitative measures of genetic variation and differentiation among maternal lineages. For Ecol Manage 197: 103-115.

GuYon, J. P. and A. KREMER (1982): Phenotypic stability of height growth, daily changes in sap pressure and transpiration in maritime pine (Pinus pinaster Ait.). Can J For Res 12: 936-946.

Harfouche, A., P. Baradat and C. E. Durel (1995): Variabilité intraspécifique chez le pin maritime (Pinus pinaster) dans le sud-est de la France. I. Variabilité des populations autochtones et des populations de l'ensemble de l'aire de l'espèce. Ann Sci For 52: 307-328.

KREMER, A. (1992): Predictions of age-age correlations of total height based on serial correlations between height increments in maritime pine (Pinus pinaster Ait.). Theor Appl Genet 85: 152-158.

LARIO, F. J. and L. OcAÑA (2004): Base mecánica de la inestabilidad de Pinus pinaster Ait. en las plantaciones juveniles de climas atlánticos. Cuad Soc Esp Cienc For 17: $175-180$.

MATZIRIS, D. I. (1982): Variation on growth and quality characters in Pinus pinaster provenances grown at seven sites in Greece. Silvae Genet 31: 168-173.

MolinA, F. (1965): Comportamiento racial del Pinus pinaster en el noroeste de España. An IFIE 2: 221-238.

PÉrez-Muñuzuri, V., M. Fernández-CAÑAmero and J. L. GÓMEZ-GEsteira (2009): The evidence for and impact of climate change in Galicia. Xunta de Galicia. Consellería de Medio Ambiente e Desenvolvemento Sostible. URL: www.meteogalicia.es, Santiago, 24 p. 
Salvador, L., R. Alia, D. Agundez and L. Gil (2000): Genetic variation and migration pathways of maritime pine (Pinus pinaster Ait) in the Iberian Peninsula. Theor Appl Genet 100: 89-95.

SAS-InstiTUTE (1999): SAS/STAT User's guide, Version 8. SAS Institute Inc., Cary, NC, 3848 p.

Tapias, R., J. Climent, J. A. Pardos and L. GiL (2004): Life histories of Mediterranean pines. Plant Ecol 171: 53-68.
ZAS, R., E. Merlo and J. Fernández-LóPez (2004): Juvenile - mature genetic correlation in Pinus pinaster Ait. under different nutrient $x$ water regimes. Silvae Genet 53: 124-129.

ZAS, R. (2006): Iterative kriging for removing spatial autocorrelation in analysis of forest genetic trials. Tree Genet Genom 2: 177-186.

\title{
Clonal Variation and Genotype by Environment Interactions in Growth and Wood Density in Eucalyptus camaldulensis at Three Contrasting Sites in Vietnam
}

\author{
By N. D. Kien ${ }^{1), 2), *}$, G. Jansson ${ }^{1,3)}$, C. HarWood ${ }^{4)}$ and C. AlmqVist ${ }^{3)}$ \\ (Received $6^{\text {th }}$ July 2009)
}

\begin{abstract}
A total of 172 clones of Eucalyptus camaldulensis were tested in three clonal tests in northern, north-central and southern Vietnam, with 32 of them planted across all three sites. At age 3-5 years, the clonal repeatabilities were $0.18-0.42$ for growth traits, $0.71-0.78$ for wood basic density and 0.56-0.66 for pilodyn penetration. Genotypic correlations between growth and density at the three sites were from -0.24 to 0.17 , and did not differ significantly from zero. Genotypic correlations between sites were $0.32-0.56$ for growth traits at age 3 years, and $0.72-0.88$ for density and pilodyn penetration. Selection gains for breast height diameter at individual sites at a selection proportion of $5 \%$ were $22-32 \%$, with minor effects on density. Selection for diameter at one site gave indirect responses in diameter at the other two sites that were only $40-60 \%$ of the gains obtainable from direct selection at those sites. This study shows that fast-growing $E$. camaldulensis clones can be selected in Vietnam with only minor effects on density. Selection for growth should be regionally based to maximize selection gain whereas clonal rankings for density will change little across regions.
\end{abstract}

Key words: clonal repeatability, correlated response, Eucalyptus camaldulensis, genotype by environment interaction, selection gain.

1) Department of Plant Biology and Forest Genetics, Swedish University of Agricultural Sciences, Box 7080, SE-750 07 Uppsala, Sweden.

2) Research Centre for Forest Tree Improvement, Forest Science Institute of Vietnam, Dong Ngac, Tu Liem, Ha Noi, Vietnam.

$\left.{ }^{3}\right)$ Skogforsk (The Forestry Research Institute of Sweden), Uppsala Science Park, SE-751 83 Uppsala, Sweden.

$\left.{ }^{4}\right)$ CSIRO Sustainable Ecosystems, Private Bag 12, Hobart 7001, Tasmania, Australia.

*) Corresponding author: Telephone +84 4 38389813, Fax +84 4 38362280. E-Mail: Nguyen.Duc.Kien@fsiv.org.vn

\section{Introduction}

Eucalyptus camaldulensis Dehnh is the most widely distributed eucalypt species, occurring primarily in riverine environments through most of the drier regions of Australia. The species displays major provenance variation (ELDRIDGE et al., 1993). Recent taxonomic studies (BROOKER and KleINIG, 2004; MCDonAlD et al., 2009) identified several sub-species, distinguished by their differing leaf, bud and fruit morphology, with distributions that are usually geographically distinct, but overlap in some areas. In a recent study of population genetics using molecular markers, this sub-specific variation was shown to align closely with genetic differentiation (BUTCHER et al., 2009). Physiological studies have revealed that provenances of $E$. camaldulensis differ in their mechanisms for adapting to drought conditions and in their water-use efficiency, and this has been related to the differing environmental conditions in their regions of origin (GIBSON et al., 1994, 1995).

Provenances occurring in northern Australia have proved adaptable to a wide range of sub-humid tropical climates and $E$. camaldulensis has emerged as one of the most widely used plantation species in the seasonally dry tropics of many countries (MIDGLEY et al., 1989; ELDRIDGE et al., 1993) including India, Thailand and Vietnam, mainly for pulpwood, poles and less often small sawlogs, with rotation times from 4 to 10 years.

Eucalyptus camaldulensis was introduced into Vietnam in the 1930s (KHA et al., 2003) and has become an important planting species both for large scale plantations and for small plantings on farms, along canals and roadsides. The total areas of eucalypt plantations in Vietnam was estimated to be 348,000 ha in 2001 (MARD, 2002), with E. camaldulensis and E. urophylla 